\title{
Measuring the Impact of Professional Competence on Teaching Effectiveness of Special Educators of Kashmir
}

\author{
Dr. Tasleema Jan ${ }^{1}$, Tahseena Bashir ${ }^{2}$ \\ ${ }^{1}$ Associate Professor, Faculty of Education, University of Kashmir \\ ${ }^{2}$ Research Scholar, Faculty of Education, University of Kashmir
}

\begin{abstract}
The term professional competence can be conceptualized as the process of acquiring those abilities, attitudes, skills and knowledge that enable teachers to discharge their professional duties and responsibilities effectively and efficiently. An effective teacher is responsible to create a warm classroom climate, to promote enthusiasm, motivation and an interactive teacher-student relationship. Also, it implies to be caring and understandable, and above all, to enhance learning. Therefore, the aim of this study was to assess the impact of various professional competence variables on teaching effectiveness of special educators of Kashmir division. A total number of 60 respondents teaching at various special schools of Kashmir division were selected for the study. The result of the study reflected that teaching effectiveness is highly affected by professional competence.
\end{abstract}

Keywords: Teaching, Competence, Professional, Special educators

\section{Introduction}

Professional competence is the ability to use appropriate qualities, attitudes, knowledge and skills in achieving success in any field of work. In the pedagogical field, professional competence plays a decisive role in achieving desirable outcomes. Without professional competence a teacher may not be able to meet the classroom challenges and may experience troubles in carrying out various tasks effectively. Professional competence includes attitudes, behaviours, administrative skills, instructional techniques, social adjustment capabilities and proper insight in specific areas which enable educators to perform their duties and responsibilities effectively in order to achieve professional success. Special educators are trained in the art of teaching and dealing with special children. Special educators bear the primary responsibility for helping exceptional children to maximize their capabilities. Special educators have a thorough understanding of the needs and problems of special children. They also know how to tackle and deal with such children in any given situation. Special educators also have the ability to distinguish and classify special children in accordance with their degree of deviation. Special educators are likely to use a wider variety of teaching strategies and techniques. Special educators cover teaching content or material at a slower pace and have wider repertoire of responses to manage students' disruptive behavior or inadequate attention which calls for acquiring professional competence for achieving professional success.

\section{Literature Review}

According to Gibbs (2002) "Teachers need to be able to survive the demands, threats and challenges within the different teaching conditions. According to him, an effective teacher needs to be tough, flexible. The effective teacher is the one who has clear objectives and set gaols of teaching. (Killen, 2006). Alton-Lee (2003) pointed out that an effective link between school and cultural context is needed. Gurney (2007) thinks that to be an effective teacher there should be an interaction among different factors including knowledge, enthusiasm and responsibility for learning. According to Borich (2000), the responsibilities of effective teachers are to have lesson clarity, instructional variety, teacher task orientation, engagement in the learning process and student success rate. Effective teachers are distinguished by their dedication to the students and to the job of teaching, and feel responsible for the achievement and success of the students and own professional development. N.V. Kuzimina (1990) stated that professional competence of a teacher is his awareness and credibility, targeted primarily on productive formation of the identity of individual. N.D. Khmel (1998) defines professional competence of the teacher as the unity of his theoretical and practical commitment to the implementation of educational activities. V.F. Gabdulhakov (2014) defines the concept of professional competence as personification of individuals, with the need to individualized instruction and education, providing opportunities for intellectual and creative growth of individual students. Thus the concept of professional competence can be without any doubt termed as the most essential elements of teaching success, and behavior modification of students.

\section{Objectives of the Study}

- To study various variables of teaching competence of special educators of Kashmir;

- To study the variables that determine teaching effectiveness of special educators of Kashmir;

- To analyze the relationship between teaching competence and teaching effectiveness . 


\section{International Journal of Science and Research (IJSR) \\ ISSN (Online): 2319-7064}

Index Copernicus Value (2015): 78.96 | Impact Factor (2015): 6.391

\section{Hypothesis}

Ho: There is no significant relation between professional competence and teaching effectiveness.

\section{Conceptual Model}

The proposed structural equation model of the professional competencies and effective teaching is presented in Figure 1. The model establishes a direct causal-effect relationship of professional competencies and effective teaching.

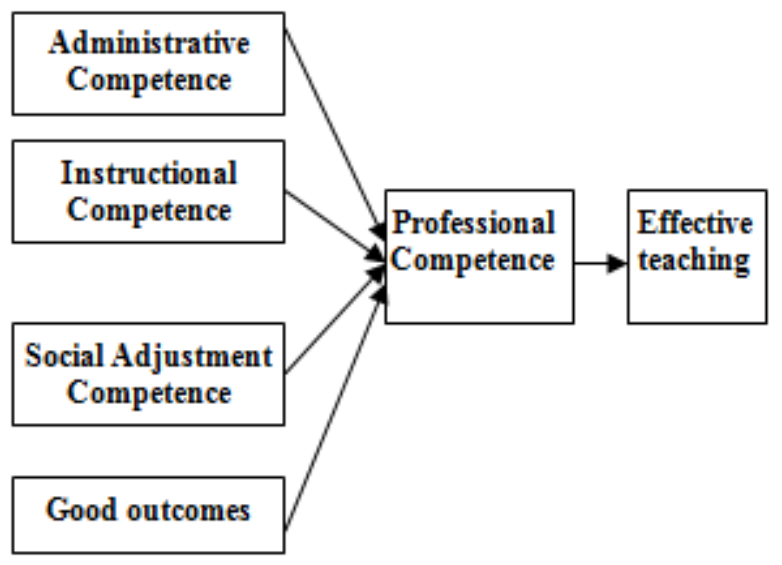

\section{Methodology}

The sample frame of the study consists of the Special Schools of Kashmir division. Using 3-point Likert-type scale, the questionnaire was developed based on employed validated scales from the existing literature, which consists of 70 items based on four variables which include administrative competence, instructional competence, social adjustment competence and good outcomes. Administrative competence was measured on 15 items; Instructional competence was measured on 17 items; Social adjustment competence was measured on 20 items and good outcomes were measured on 18 items. A total number of 60 questionnaires were distributed to the teachers of Special Schools of Kashmir division. The collected data was analyzed by using SPSS.

\section{Findings}

Table 1: Means and Standard Deviations for the Study Variables

\begin{tabular}{|c|c|c|c|c|c|}
\hline Variables & $\mathrm{N}$ & Mean & SD & 't'-value & Sig \\
\hline Instructional Competence & 60 & 6.11 & .89 & 16.39 & 0.00 \\
\hline Administrative Competence & 60 & 5.39 & .87 & 15.43 & 0.00 \\
\hline Social Adjustment Competence & 60 & 5.19 & .85 & 14.54 & 0.00 \\
\hline Good Outcomes & 60 & 5.02 & .84 & 14.23 & 0.00 \\
\hline
\end{tabular}

Table-1 presents the value of means and standard deviation for each variable in the questionnaire. It is clearly found from the table that the Instructional Competence (6.11) was given much importance by the respondents while the Good Outcomes with least mean (5.02) indicating less importance given by the sample individuals.
Table 2: Linear Regression for Impact of Instructional Competence on teaching effectiveness

\begin{tabular}{|l|c|c|c|c|c|c|c|}
\hline \multirow{2}{*}{$\begin{array}{l}\text { Independent } \\
\text { Variable }\end{array}$} & \multicolumn{5}{|c|}{$\begin{array}{c}\text { Dependent Variable: } \\
\text { Teaching effectiveness }\end{array}$} & \multirow{2}{*}{$\begin{array}{c}\text { Hypothesis } \\
\text { decision }\end{array}$} \\
\cline { 2 - 6 } & $\mathrm{R}$ & $\mathrm{R}^{2}$ & $\mathrm{~F}$ & $\beta$. & \multicolumn{1}{c}{$\mathrm{t}$ 'value } & Sig. & \\
\hline $\begin{array}{l}\text { Professional } \\
\text { competence }\end{array}$ & .739 & .608 & 206.499 & .739 & 14.37 & .000 & Rejected \\
\hline $\mathrm{P}<001$ & & & & & \\
\hline
\end{tabular}

The results of regression analysis present in the above table indicate that Professional Competence had a positive relationship with Teaching Effectiveness $(\beta=.739, \mathrm{P}=.000)$. More specifically, Professional Competence $\left(R^{2}\right) 54.6 \%$ of variance in Teaching Effectiveness, indicates that Professional Competence is a good predictor in Teaching Effectiveness. As a result the Null Hypothesis is rejected.

\section{Conclusion}

Professional Competence is a determinant of teaching effectiveness. To conclude, to be an effective special educator is not an easy task. In fact, it is a complex process. Effective special teachers need to have good professional and personal skills such as emotional stability, patience, content knowledge, good planning, clear goals, effective communication, good classroom management and realistic expectations from students. Besides, they need to feel responsible for the students learning process, regardless of the student's aptitude towards learning. The teachers having effective personal and professional skills serve as lifelong learners. Moreover, the effective teacher will combine professionalism with care, understanding, fairness, kindness and empathy. They also have to be enthusiastic and motivated about teaching and learning. They have to create warm classroom environment and have to show sense of belongingness. Special educators of Kashmir division were found to have such qualities. To finalise, it can be said that the special educators of Kashmir division have the capacity to inspire students reach their fullest potential. The results of the study clearly depict that special educators of Kashmir division have high professional competence. They possess mastery over special educational content, teaching techniques and use of special instructional media which is evident from there effective teaching.

\section{References}

[1] Alton-Lee, A. (2003) "Quality teaching for diverse students in schooling: Best evidence synthesis", Wellington: Ministry of Education.

[2] Borich, G.D. (2000) "Observation skills for effective learning", 4th edit. Prentice Hall, UK

[3] Gabdulchakov, V. F. (2014). The Problems of Language Personality Formation in Russia (the Analysis of Language Processes and Pedagogical Technologies) Procedia-Social and Behavioral Sciences. Third Annual International Conference "Early Childhood Care and Education", 146, 158-162.

[4] Gabdulkhakov, V. F. (2014). Personification of Multicultural Education in the Universities of Russia (Analysis of Training Specialists for Kindergartens) Procedia-Social and Behavioral Sciences. Third 


\section{International Journal of Science and Research (IJSR) \\ ISSN (Online): 2319-7064}

Index Copernicus Value (2015): 78.96 | Impact Factor (2015): 6.391

Annual International Conference "Early Childhood Care and Education", 146, 129-133.

[5] Gibbs, C.J. (2002). "Effective teaching: exercising selfefficacy and thought control of action" Auckland University of Technology, New Zealand, Annual Conference of the British Educational Research Association Exeter England.

[6] Gurney, P. (2007) "Five factors for effective teaching" Journal of Teachers' Work, Vol. 4, Issue 2, 89-98

[7] Kuz'mina, N. V. (1990). Professionalism of personality of teacher (p. 149). Moscow: Academy of pedagogical sciences.

[8] Killen, R. (2006) "Effective teaching strategies Lessons for research and practice" 4th edit., Thomson, Social Science Press, UK

[9] Smith, F. (1995) "Let's declare education a disaster and get on with our lives". Phi Delta Kappan, 76, 584-590

[10] Stronge, J.H., Tucker, P.D. \& Hindman, J.L. (2004) "Handbook for qualities of effective teachers" Association for Supervision and Curriculum Development, Alexandria, VA, USA 